\title{
THE MEANINGS OF MODAL AUXILIARY VERBS IN THE MOVIE THE PERKS OF BEING A WALLFLOWER
}

\author{
Herlina Endah Atmaja
}

\section{INTISARI}

Penelitian ini bertujuan menginvestigasi makna kata kerja bantu modal dalam film The Perks of being a Wallflower. Secara khusus, penelitian ini bertujuan mengidentifikasi dan mengklasifikasi kata kerja bantu modal menurut maknanya. Data yang digunakan dalam penelitian ini adalah dialog yang berisi kata kerja bantu modal. Kata kerja bantu modal dianalisa secara semantic dan pragmatic. Berdasarkan hasil data, 171 kata kerja bantu modal ditemukan. Kata kerja bantu modal yang paling sering digunakan adalah kata kerja bantu modal will (28.7\%), diikuti oleh can (24.0\%), would (21.6\%), could (14.0), should $(7.0 \%)$, might (2.9\%), and must (1.8\%). Dari 171 kata kerja bantu modal, 43 (25.1\%) digunakan untuk mengungkapkan makna epistemic, 23 (13.4\%) digunakan untuk mengungkapkan makna deontic, dan 105 (61.3\%) digunakan untuk mengungkapkan makna dinamis. Dalam penelitian ini ditemukan bahwa kata kerja bantu modal paling sering digunakan untuk mengekspresikan makna dinamis.

Kata kunci: kata kerja bantu modal, makna epistemic, makna deontic, dan makna dinamis.

\begin{abstract}
This research attempts to investigate the meanings of modal auxiliary verbs in the movie The Perks of being a Wallflower. In particular, it aims to identify and classify the modal auxiliary verbs according to their meanings. The data used in this research were dialogues containing modal auxiliary verbs. The modal auxiliary verbs are analyzed semantically and pragmatically. Based on the data analysis, 171 modal auxiliary verbs were found in the movie. The most commonly used modal auxiliary verb in the movie is the modal auxiliary will $(28.7 \%)$, followed by can $(24.0 \%)$, would $(21.6 \%)$, could $(14.0 \%)$, should (7.0\%), might $(2.9 \%)$, and must (1.8\%). From the 171 modal auxiliary verbs, $43(25.1 \%)$ are used to express epistemic meanings, $23(13.4 \%)$ are used to express deontic meanings, and $105(61.3 \%)$ are used to express dynamic meanings. It was found in this research that the modal auxiliary verbs are most frequently used to express dynamic meanings.
\end{abstract}

Key words: modal auxiliary verbs, epistemic meaning, deontic meaning, and dynamic meaning. 


\section{INTRODUCTION}

Modal auxiliary verbs are an important part of the grammatical system of English. They can express many different meanings. Leech (2006: 63-64) argues that a modal auxiliary is "a member of a small class of verbs that have meanings relating to modality, that is to such concepts as possibility or permission (can, may), obligation, necessity or likelihood (must, should), prediction, intention or hypothesis (will, would)".

Modal auxiliary verbs serve useful functions in expressing tenses, moods, and conditions. Many modal auxiliary verbs are used in daily interaction. It can be said that modal auxiliary verbs have an important role in interaction especially because they can express many different meanings such as possibility, ability, and permission.

It is interesting to observe that such modal auxiliary verbs are commonly used in daily interaction. Therefore, this paper attempts to address the questions what kinds of modal auxiliary verbs are used in the movie The Perks of being a Wallflower and what meanings are expressed by these modal auxiliary verbs in the movie.

This research investigates the meanings of modal auxiliary verbs in the movie The Perks of being a Wallflower. This research focuses on the semantic and pragmatic meanings of the verbs. Semantic and pragmatic analyses are used to identify and classify the verbs according to their meanings. Although the data were obtained from the movie, the data in this research were not analyzed phonologically and syntactically.

The data source for this research is the subtitle of the movie The Perks of Being a Wallflower, which was published in 2012 by Subscene (subscene.com) and accessed on 5 November 2013. The movie was directed by Stephen Chbosky and it was released on September 21, 2012. The data used for this research were dialogues containing modal auxiliary verbs (MAV). The criteria proposed by Huddleston and Pullum (2005) were adopted to identify and classify the meanings of the modal auxiliary verbs. Afterwards, the data were analyzed semantically and pragmatically for their meanings in the context of the dialogues. The meaning families of the modal auxiliary verbs are divided into epistemic modal auxiliary verbs, deontic modal auxiliary verbs, and dynamic modal auxiliary verbs.

\section{MOOD AND MODALITY}

Mood is the grammatical coding of modal meaning in verb inflection. "It can be said simply to be an indication of the speaker's attitude towards what he or she is talking about" (Brinton, 2000: 115). There are three types of inflectional moods which express modal meanings: imperative mood, subjunctive mood, and indicative mood.

Huddleston and Pullum (2005: 53) introduce modality briefly as a broad term for the kinds of meanings characteristically expressed by the modals such as possibility, ability, and permission. Huddleston and Pullum (2005: 54) mention that modality has three main families of meanings: epistemic, deontic, and dynamic.

\section{MODAL AUXILIARY VERBS}

Huddleston and Pullum (2005: 37) divide verbs generally into two main classes: lexicalverbs and auxiliary verbs. Lexical verbs are the main verbs in a phrase or sentence while the general definition of auxiliary verbs is that "they denote a closed class of verbs that are characteristically used as markers of tense, mood, aspect, and voice, i.e. they are grammaticalized" (Huddleston and Pullum, 2002:102 in Kukucz, 2009: 2).

Huddleston and Pullum (2005: 37) propose that auxiliary verbs can be divided into two classes: modal auxiliary verbs and non-modal auxiliary verbs. A modal auxiliary is "a member of a small class of 
verbs that have meanings relating to modality, that is to such concepts as possibility or permission (can, may), obligation, necessity or likelihood (must, should), prediction, intention or hypothesis (will, would)" (Leech, 2006: 63-64).Nonmodal auxiliary verbs (be, have, and do) are the verbs that have a function either as main verbs or as auxiliaries (Kukucz, 2009: 3).

According to Quirk et al. (1985: 137) modal auxiliary verbs can be divided into two classes: central modals and marginal modals. Central modals includes can, could, may, might, must, shall, should, will, and would. Marginal modals are usually treated as main verbs. Marginal modals include dare, need, and used to. This research only focuses on central modal auxiliary verbs (can, could, may, might, must, shall, should, will, and would).

\section{POLYSEMY VS MONOSEMY}

A word that has many meanings is called polysemy, and a word that has one meaning is called monosemy. Following Collins (2009), this paper adopts the polysemy approach to the meaning of modal auxiliary verbs.

\section{TYPES OF MEANINGS OF MODAL AUXILIARY VERBS IN THE PERKS OF BEING A WALLFLOWER}

Based on the data analysis 171 modal auxiliary verbs were found. Table 1 shows the frequency and the distribution of modal auxiliary verbs in the movie.

The table shows that the most commonly used modal auxiliary verb is the modal auxiliary verb will (28.7\%), followed by the modal auxiliary verbs can $(24.0 \%)$, would $(21.6 \%)$, could (14.0\%), should (7.0\%), might (2.9\%), and must (1.8\%). The modal auxiliary verbs may and shall are not used at all in the movie.
Table 1. The Frequency and Distribution of Modal Auxiliary Verbs in the Movie

\begin{tabular}{rlrr}
\hline \multirow{2}{*}{ No. } & \multirow{2}{*}{$\begin{array}{c}\text { Modal Auxiliary } \\
\text { Verbs }\end{array}$} & \multicolumn{2}{c}{ Total } \\
\cline { 3 - 4 } 1. & Can & 41 & 24.0 \\
\hline 2. & Could & 24 & 14.0 \\
\hline 3. & May & 0 & 0 \\
\hline 4. & Might & 5 & 2.9 \\
\hline 5. & Must & 3 & 1.8 \\
\hline 6. & Shall & 0 & 0 \\
\hline 7. & Should & 12 & 7.0 \\
\hline 8. & Will & 49 & 28.7 \\
\hline 9. & Would & 37 & 21.6 \\
\hline & & 171 & 100.0 \\
\hline
\end{tabular}

\section{The Meanings of Modal Auxiliary Verbs}

All of the modal auxiliary verbs were analyzed and classified according to their modal meanings into epistemic meanings, deontic meanings, and dynamic meanings. Table 2 shows the frequency and the distribution of modal auxiliary verbs across the three types of modal auxiliary meanings. It shows that the modal auxiliary verbs are most frequently used to express dynamic meaning $(61.3 \%)$. This type of dynamic meaning is mostly expressed by the modal auxiliary verbs will $(22.2 \%)$ and can (17.5\%). Epistemic meaning (25.1\%) in the movie is especially expressed by the modal auxiliary verbs would $(10.5 \%)$ and will $(6.4 \%)$. Deontic meaning $(13.4 \%)$ is expressed by the modal auxiliary verbs should $(7.0 \%)$ and can (6.4\%). In short, the modal auxiliary verbs are most frequently used in the movie to express dynamic meanings. This indicates that the occurrence of the modal auxiliary verbs in this movie are used to express many kinds of meanings that happen to the speaker that has connection to ability and volition. 
Table 2. The Frequency and Distribution of Modal Auxiliary Verbs in the Movie According to Their Meanings.

\begin{tabular}{|c|c|c|c|c|c|c|c|c|c|}
\hline \multirow{2}{*}{ No. } & \multirow{2}{*}{ MAV } & \multicolumn{2}{|c|}{ Epistemic } & \multicolumn{2}{|c|}{ Deontic } & \multicolumn{2}{|c|}{ Dynamic } & \multicolumn{2}{|c|}{ Total } \\
\hline & & No. & $\%$ & No. & $\%$ & No. & $\%$ & No. & $\%$ \\
\hline 1 & Can & 0 & 0 & 11 & 6.4 & 30 & 17.5 & 41 & 24.0 \\
\hline 2 & Could & 6 & 3.5 & 0 & 0 & 18 & 10.5 & 24 & 14.0 \\
\hline 3 & May & 0 & 0 & 0 & 0 & 0 & 0 & 0 & 0 \\
\hline 4 & Might & 5 & 2.9 & 0 & 0 & 0 & 0 & 5 & 2.9 \\
\hline 5 & Must & 3 & 1.8 & 0 & 0 & 0 & 0 & 3 & 1.8 \\
\hline 6 & Shall & 0 & 0 & 0 & 0 & 0 & 0 & 0 & 0 \\
\hline 7 & Should & 0 & 0 & 12 & 7.0 & 0 & 0 & 12 & 7 \\
\hline 8 & Will & 11 & 6.4 & 0 & 0 & 38 & 22.2 & 49 & 29.0 \\
\hline 9 & Would & 18 & 11.0 & 0 & 0 & 19 & 11.1 & 37 & 22.0 \\
\hline & Total & 43 & 25.1 & 23 & 13.4 & 105 & 61.3 & 171 & 100.0 \\
\hline
\end{tabular}

The sections below discuss in detail the modal auxiliary verbs used to express epistemic meanings, deontic meanings, and dynamic meanings.

\section{Epistemic Modal Auxiliary Verbs}

Epistemic modality is concerned with the speaker's attitude and expresses the meanings via the concepts of human interaction (Collins, 2009: 21). It also has a close connection with possibility and belief. Five modal auxiliary verbs could, might, must, will, and would are used to express epistemic meanings in this movie. Each of them will be discussed in detail below.

\section{a. Epistemic could}

Could can express temporal and hypothetical uses. According to Collins (2009: 105-106), epistemic could commonly occur in a past time or is used to identify a past situation. Epistemic could can occur in constructions of if-clause, constructions of wish, counterfactual situation, unactualized possibility, uncertainty, and likelihood. In example (1) below, epistemic could occurs in constructions of wish.
Mary and Patrick are in a club. They see Patrick's step-sister (Sam) dancing with her new boy friend. Mary asks Patrick about Sam's ex-boy friend. Patrick just answers by saying that he only wants his step-sister stop playing dumb.

Mary: Who could forget Mr. Car Wash Loser?

Patrick: I just hope she could stop playing dumb with these guys. I keep telling her. Don't make yourself small.

In example (1) could occurs in a construction of wish. Could implies Patrick's hope for his sister that he wants his sister to stop playing dumb.

\section{b. Epistemic might}

Might is the preterite form of may. Might can be used to indicate future time and present time. Below is an example of the use of epistemic might:

(2) $01: 36: 51,940-01: 37: 07,752$

(PW.EP.M.5)

In his last letter, Charlie says that he does not know if he will write lettersagain or not because he wants to participate in life.

Charlie's letter: I don't know if I will have the time to write any more letters because I might be too busy trying to participate. So, if this does end up being the last letter, I just want you to know that I was in a bad place before I started high school.

Might in example (2) indicates how life is "possibly" going to be. Might refers to possibility in the future because in his letter, Charlie writes that he does not know if he will write letters or not because he is probably busy trying to participate in life.

\section{(1) $00: 35: 53,969-00: 36: 03,018$}

(PW.EP.CO.11) 


\section{c. Epistemic must}

Epistemic must expresses a logical certainty or logical necessity based on what is known by the speaker (Collins, 2009: 38). According to Fattah (2011: 49), epistemic must expresses a stronger degree of certainty than may, might or could whether in present or past events. The epistemic necessity expressed by must, for example, is not to be taken as the realization or verification of the actuality or non-actuality of the proposition, but as a logical conclusion. It refers to the speaker's confidence, as shown in the example below.

(3) $00: 58: 19,566-00: 58: 25,519$

(PW.EP.MU.3)

Mary goes to Charlie's home. She knocks at the door and then Charlie's mother opens it while saying to convince that she is Mary Elizabeth.

Charlie's mother: You must be Mary Elizabeth.

Mary: Yes.

Charlie's mother: It's so nice to meet you.

Mary: You, too, Mrs. Kelmeckis.

In example (3) there is subjectivity, where Charlie's mother is confident that the conclusion is the only one possible. Charlie's mother emphasizes by using the word must as a certainty that the girl she meets is Mary Elizabeth because Charlie has told her that Mary Elizabeth will come to their home. Therefore, when she opens the door and meets a girl, she concludes that the girl is Mary Elizabeth.

\section{d. Epistemic will}

Epistemic will can be used to express futurity, prediction, and predictability and relates to the speaker's belief and knowledge (Collins, 2009: 127). According to Collins (2009: 127-130), epistemic will can be used with passive voice, non- agentive verbs, stative verbs, in the existential there construction, and itextraposition construction. In example (4) will is used to express futurity.

(4) $00: 14: 46,982-00: 14: 52,715$

(PW.EP.W.5)

Sam and Patrick escort Charlie back to his home. Before leaving Charlie's home, Patrick thanks Charlie for paying the food. Charlie says it is okay for him and he asks them that perhaps they will see at school.

Patrick: Hey, thanks for paying, Charlie. Charlie: Oh, no problem. Thank you guys for the ride. Maybe I'll see you around in school?

Will here indicates futurity because it refers to a future action which is possible or impossible to happen. There is also the word maybe that indicates possibility. It is possible that Charlie meets Patrick and Sam at school. This is because it was the first time for them to know each other. They are also not in one class because Patrick and Sam are Charlie's seniors.

\section{e. Epistemic would}

Like preterite could and might, would can also express temporal and hypothetical uses. Hypothetical would is found in the unreal conditional constructions and constructions of wish and involves such features as diffidence, tack, politeness and unassuredness (Collins, 2009: 141). In example (5) would is used in a construction of wish.

(5)

00:33:53,968-00:34:07,864 (PW.EP.WO.17)

Charlie asks Sam about what happens to her because she looks sad. Sam says that she gets her SAT result and the result is not really good. And then, Charlie tries to 
console her. He tries to convince that she can do it.

Sam: Yeah, it's just if I'm going to Penn State main campus. I have to do much better. I wish I would have studied freshman year. I was a bit of a mess.

Charlie: I'll help you study for the next one.

Would is used in a construction of wish, that is, Sam's wish. When she was freshman year, she often got drunk at the party. She was not serious during freshman year, so that's why she wishes that she could have freshman year.

\section{Deontic Modal Auxiliary Verbs}

According to Collins (2009: 22), deontic modality occurs when the factors impinging on the actualization of the situation referred to in the utterance involve some type of authority - as when a person or a set of rules or a social convention is responsible for the imposition of an obligation or a granting of permission. Deontic modality is concerned with necessity or possibility. Thus, it is used to express desires, wants, commands, obligation, necessity, undertaking, and permission (Fattah, 2011: 47). The modal auxiliary verbs can and should in the movie are used to express deontic meanings.

\section{a. Deontic can}

It has been argued by linguists that deontic can is semantically distinct from deontic may. The difference is that can is objective and may is subjective (Vanparys, 1987: 232 in Collins, 2009: 100). Deontic can states that the speaker has permission and deontic may states that the speaker grants permission to the hearer. This is an example:

(6) $01: 36: 02,790-01: 36: 04,546$

(PW.DE.C.34)
Patrick comes to Charlie's home. He asks for permission to Charlie's mother because he wants to invite Charlie to come out and play with him.

Patrick: Can Charlie come out and play?

In example (6) can expresses a request for permission. Patrick asks Charlie's mother if Charlie is allowed to come out and play with him.

\section{b. Deontic should}

Should has medium strength modality. It expresses suggestion or advice. Below is an example illustrating the use of deontic should.

$$
\text { 00:04:51,531-00:05:03,096 }
$$$$
\text { (PW.DE.SH.1) }
$$

Patrick's teacher calls him Nothing. When the lesson starts, his teacher asks him to read.

Teacher: Nothing, why don't you read first? Patrick: Alright. Chapter 1. Surviving your fascist shop teacher, who needs to put kids down to feel big. Oh, wow. This is useful guys. We should read on.

In example (7) should indicates suggestion. Patrick suggests that they should read on.

\section{Dynamic Modal Auxiliary Verbs}

Dynamic modal auxiliary verbs are used to express ability and volition. In this research, modal auxiliary verbs are most commonly used to express dynamic meanings (accounting for 61.0\%). The modal auxiliary verbs can, could, will, and would in the movie are used to express dynamic meanings.

\section{a. Dynamic can}

This research identifies two uses of dynamic can in the movie, theoretical possibility and dynamic ability. Dynamic 
ability is the most common used in the movie. It involves the potentiality of the subject to a situation. Below is an example of the use of modal auxiliary verbs can expressing dynamic ability:

\section{(8) 00:15:29,573-00:15:34,471 \\ (PW.DY.C.5)}

Charlie's sister (Candace) has a conflict with Derek (her boy friend) and Charlie sees what is going on with them and tries to see closer. However, Candace prevents him and asks him to go.

Candace: Charlie, Charlie, just go. I can handle it. Just don't wake up mom and dad.

In example (8) can indicates that Candace has the ability to do what she says. She is able to handle the problems that happen to her and Derek.

\section{b. Dynamic could}

Dynamic could is the preterite form of can. This research identifies the use of dynamic could in the movie, dynamic ability. Below is an example of could expressing dynamic ability:

(9) 00:14:01,814-00:14:09,103 (PW.DY.CO.7)

Charlie and Sam are in the cafeteria. Sam asks Charlie about what he will do.

Charlie: Well, My Aunt Helen said I should be a writer, but I don't know what I'd write about.

Sam: You could write about us.

Charlie: Yeah.

Could in example (9) implies that Charlie is able to write about their story. He often writes especially about the journey of his life.

\section{c. Dynamic will}

"Dynamic will expresses the potential for an activity or event deriving, characteristically, from the subjectreferent's volition" (Collins, 2009: 131). Dynamic will can also express ability, futurity, habit, intention, power, and willingness. Dynamic will in this movie is used to express willingness, futurity, and volition. Below is an example of the use of modal auxiliary verb would expressing willingness.

(10) 00:06:32,975-00:06:36,297

(PW.DY.W2)

Mr. Anderson is asking questions to the students. First, he is asking about the name of the author of a book. Only one student answers it, but unfortunately the answer is wrong. And then he gives the second question and tells the students that he will give a free " $A$ " if they can give the right answer.

Mr. Anderson: I'll give you a free "A" on anything till the final term paper if you get it right.

In example (10) will expresses willingness. $\mathrm{Mr}$. Anderson is willing to give a free " $\mathrm{A}$ " if the students give the right answer.

\section{d. Dynamic would}

Dynamic would is the preterite form of will. It commonly occurs in a form of volition which is the same as dynamic will. Yet, the difference is that would is considered to show politeness in a would request or in a use of tentative epistemic meaning. Below is an example illustrating the use of dynamic would. 
(11) $00: 14: 53,223-00: 14: 57,359$ (PW.DY.WO.11)

Patrick plays music loudly and Sam complains.

Sam: God, would you turn that down? You're gonna make us deaf. Patrick: So be it! It's Rock and roll.

In example (11) would expresses a polite request. Sam politely asks Patrick to turn down the volume of music because it can make them deaf.

\section{CONCLUSION}

This study deals with the meanings of modal auxiliary verbs in the movie The Perks of being a Wallflower. The results of this research show that 171 modal auxiliary verbs were found in the movie. The most commonly used modal auxiliary verbs in the movie is the modal auxiliary will $(28.7 \%)$, followed by can $(24.0 \%)$, would $(21.6 \%)$, could (14.0\%), should (7.0\%), might $(2.9 \%)$, and must (1.8\%). The movie runs for 102 minutes so it was found approximately 16 modal auxiliary verbs per 10 minutes. It can be concluded that the modal auxiliary verbs have an important role in interaction.

From the 171 modal auxiliary verbs, $43(25.1 \%)$ are used to express epistemic meanings, $23(13.4 \%)$ are used to express deontic meanings, and $105(61.3 \%)$ are used to express dynamic meanings. Therefore, it can be concluded that the modal auxiliary verbs in the movie The Perks of being a Wallflower are most frequently used to express dynamic meanings. This may be because they are used to express many kinds of meanings related to ability and volition to a situation.

Further research on the same topic is needed to see whether most modal auxiliary verbs are used to express dynamic meanings. Different data sources such as articles, journals, novels, plays, speeches, newspaper, and magazines might be used in such research.

\section{REFERENCES}

Aarts, Bas \& April McMahon (Eds). 2006. The Handbook of English Linguistics. Oxford: Blackwell.

Brewer, Nicola M. 1987. Modality and Factivity: One Perspective on the Meaning of the English Modal Auxiliaries. Leeds: The University of Leeds Department of Linguistics and Phonetics. Unpublished PhD dissertation.

Brinton, Laurel J. 2000. The Structure of Modern English: A Linguistic Introduction. Amsterdam: John Benjamins.

Collins, Peter. 2009. Modals and QuasiModals in English. Netherlands: Radopi.

Fattah, Hussein Abdul. 2011. A FormalFunctional Analysis of the English Modal Auxiliaries. Jordan Journal of Modern Languages and Literature Vol 3 No.1, pp. 39-63.

Gove, Philip Babcock (Ed). 1971. Webster's Third New International Dictionary of the English Language Unabridged.

Massachusetts: G. \& C. Merriam Company.

Gustova, Iveta. 2011. The Ways of Expressing Epistemic (Extrinsic) Modality in Spoken English.Pilsen: University of West Bohemia Faculty of Education. Unpublished Undergraduate Thesis.

Hornby, A.S. 2006.Oxford Advanced Learner's Dictionary of Current English $8^{\text {th }}$ Edition. Oxford: Oxford University Press. 
http://www.tesol-direct.com/guide-toenglish-grammar/modal-auxiliaryverbs. Retrieved on January 2, 2013; 19:50.

Huddleston, Rodney \& Geoffrey K. Pullum. 2005. A Student's Introduction to English Grammar. Cambridge: Cambridge University Press.

Kukucz, Marta. 2009. Characteristics of English Modal Verbs. Olomouc: FilozofickáFakultaUniverzityPalackéh o. Unpublished Undergraduate Thesis.

Leech, Geoffrey. 2006. A Glossary of English Grammar. Edinburgh: Edinburgh University Press.

Quirk, R., Greenbaum, S., Leech, G. \&Svartvik, J. 1972.A Grammar of Contemporary English. Oxford: Longman.
Quirk, R., Greenbaum, S., Leech, G. \&Svartvik, J. 1985.A comprehensive grammar of the English language. Oxford: Longman.

Subscene. 2013. The Perks of being a Wallflower. (http://subscene.com/subtitles/theperks-of-being-awallflower/english/664178). Retrieved on November 5, 2013; 19:50.

Sudirman. 2010. Analysis on Student's Difficulties in Learning Modal Auxiliaries "Can" and "Could". Jakarta: Universitas Islam NegeriSyarifHidayahtullah. Unpublished Undergraduate Paper.

Widyaswara, Rachmalita. 2013. Modal Auxiliary Verbs in Barack Obama's 2009 Inaugural Address. Yogyakarta: UGM. Unpublished Undergraduate Paper. 